\title{
ACM 分野における炭素繊維中間基材の開発動向
}

西村

明

\section{1.はじめに}

織物に代表される緎維高次加工品は，その時代の 先端分野とのかかわりが大きい.18世紀から19世紀 にかけ，ライト兄弟に代表される熱血漢らが空を飛 ぼうとロマンを求めていたが，この翼にコーティン グされた絹織物が使われていたし1)，20世紀初め，実 用機の翼材料として麻織物が採用されていた2!. 最 近の民間航空機は, 燃費や大量輸送効率改善のた め, 軽量化が求められ, 構造材の CFRP (Carbon Fiber Reinforced Plastics）化が進みつつあり，す でに実用化段階に入っている 2 次構造材の 70 $80 \%$ が炭素繊維織物を強化材とした複合材料で作 られている。

複合材料は「二つ以上の材料を組み合わせること によって，単体で持ち合わさなかった特性を発現 し, 新しい機能を実現する材料」と定義することが できる. 自然界では竹や生体材料, 古くは土塀など が複合材料の範疇に入るが，注目されるようになっ たのはPAN 系炭素緎維の出現に負うところが大き い．金属を含めた既存材料で到達することができな かった，比強度と比弾性率の大きな材料を作り出す ことが可能となり, ACM (Advanced Composite Materials; 先端複合材料) と呼ばれるようになっ た.

さて，炭素繊維複合材料は，炭素繊維の集合体と 樹脂などのマトリックスから構成されているが, ACM における䋐維集合体は, 材料の力学的特性や 信頼性といった観点から, 連続繊維から構成され,
その繊維は全て制御された方向に配向している。 そ の集合体は，1 万向材や織物などのシート材料の積 層体であったり，また，最近，開発が進められてい る三次元織物や三次元プリフォームなよ゙の NEARNET-SHAPE 型であり, 繊維高次加工技術とのか かわりが大きい.

複合材料では, 強化繊維が構造材料としての機械 的特性を担う役割を果たすため, 繊維配向の状態が 重要となる. 一方, 成形加工のための予備的形態で ああり，成形加工の効率に及ぼす影響む大きい，炭 素繊維と成形法の最近の動向についても若干触れ る。なお，ここで取り扱う中間基材は, 繊維配向や 構造に特徴を有する繊維材料とし, 樹脂に特長を有 するプリプレグなどは割愛した.

\section{PAN 系炭素繊維の進歩}

1970年代の PAN 系炭素繊維（CF）の技術開発課 題は, 量産による品質の安定化とコストダウンであ った．1980年代に入り，スポーッ・レジャ一分野へ

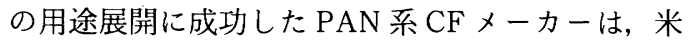
国の航空機メ一カーから航空機の一次構造材料への 適用を目標とした，引張破断伸度が $2.0 \%$ 以上の高 強度・高弾性率 $\mathrm{CF}$ の開発要請屯あり，この開発競 争に拍車がかかった。図1に示したように, 現在, 強度面では東レの開発した「トレカ」T1000 ${ }^{3}$ (引張 強度 : $7.06 \mathrm{GPa}$, 引張弾性率 : $294 \mathrm{GPa}$, 引張破断 伸度：2.4\%) が最高であり, 弾性率では $590 \mathrm{GPa}^{4}$ の CF が開発されている.

A. Nishimura, 東レ(株複合材料研究所, Developments of Fabric Structures for Advanced Composite Materials, Composite Materials Labs, Toray Industries, Inc. 


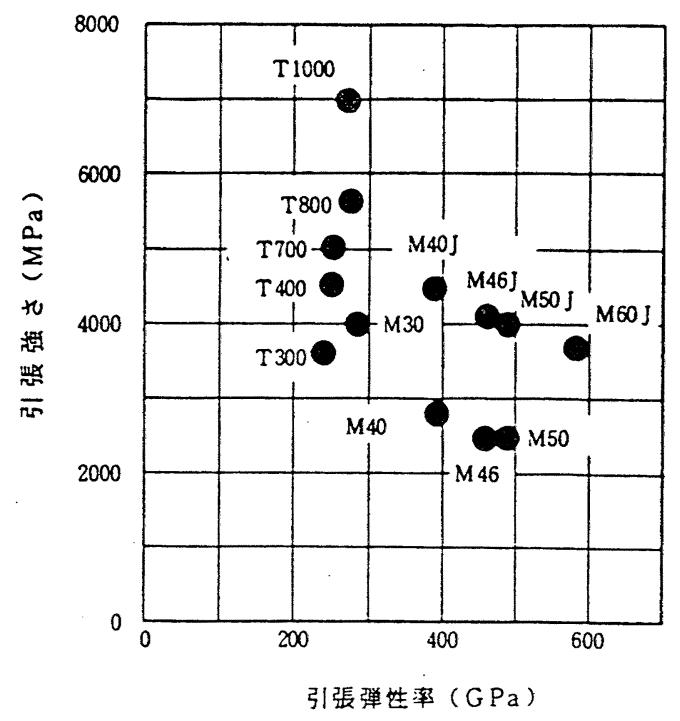

図 1 炭素繊維の強度と弾性率

\section{3. 炭素繊維中間基材の進歩}

炭素繊維複合材料では，CF の特性のみならず繊 維の方向が機械的特性を支配するので, 所要の方向 に繊維配列させることが肝要となる. 形状, 繊維配 列法など種々研究・開発されており, 繊維集合体で ある基材の幾何学的形状を次元数, 繊維配列の方位 数を軸数で表現し, 種々の中間基材が表 1 のように
分類されている.

以下, 当社が PAN 系CF「トレカ」の工業化開始 と同時に研究・開発に着手し，開発に成功した $\mathrm{CF}$ 中間基材について記載する。なお，詳細については 参考文献を参照願いたい.

\section{1 炭素繊維織物}

PAN 系の高強度, 高弾性率の CF が出現したと き, 㵶維の伸びおよび糸の結節強さが小さく，繊維 高次加工技術の常識では，とても製織加工できる状 態ではなかった。 また，当時，ガラス繊維強化プラ スチックなどの経験から， CF を織物の形態にして 使う之，物性上不利であるとされていた5).

製織技術検討の報告は割愛するが，当時の CF の 品質は不安定であり, 製織工程での毛羽発生, すな わち繊維の切断も大きく，準備工程を含めた製織工 程の各履歴を受けた CF を採集してコンポジット物 性の追跡調査を行った。 その結果, 織物用のコンポ ジット物性は製織工程での履歴より，むしろ織物構 造（織物規格）の影響を大きく受けることが分かっ $た^{6.7)}$.

実際に，樹脂中における織物構造をモデル化し， 有限要素法で応力解析を行うと, たて糸とよこ系の 交点で応力集中係数が最も大きくなり, 織角度 $\theta$ が 大きくるとかなり大きな応力集中が発生することが

表 1 中間基材の種類

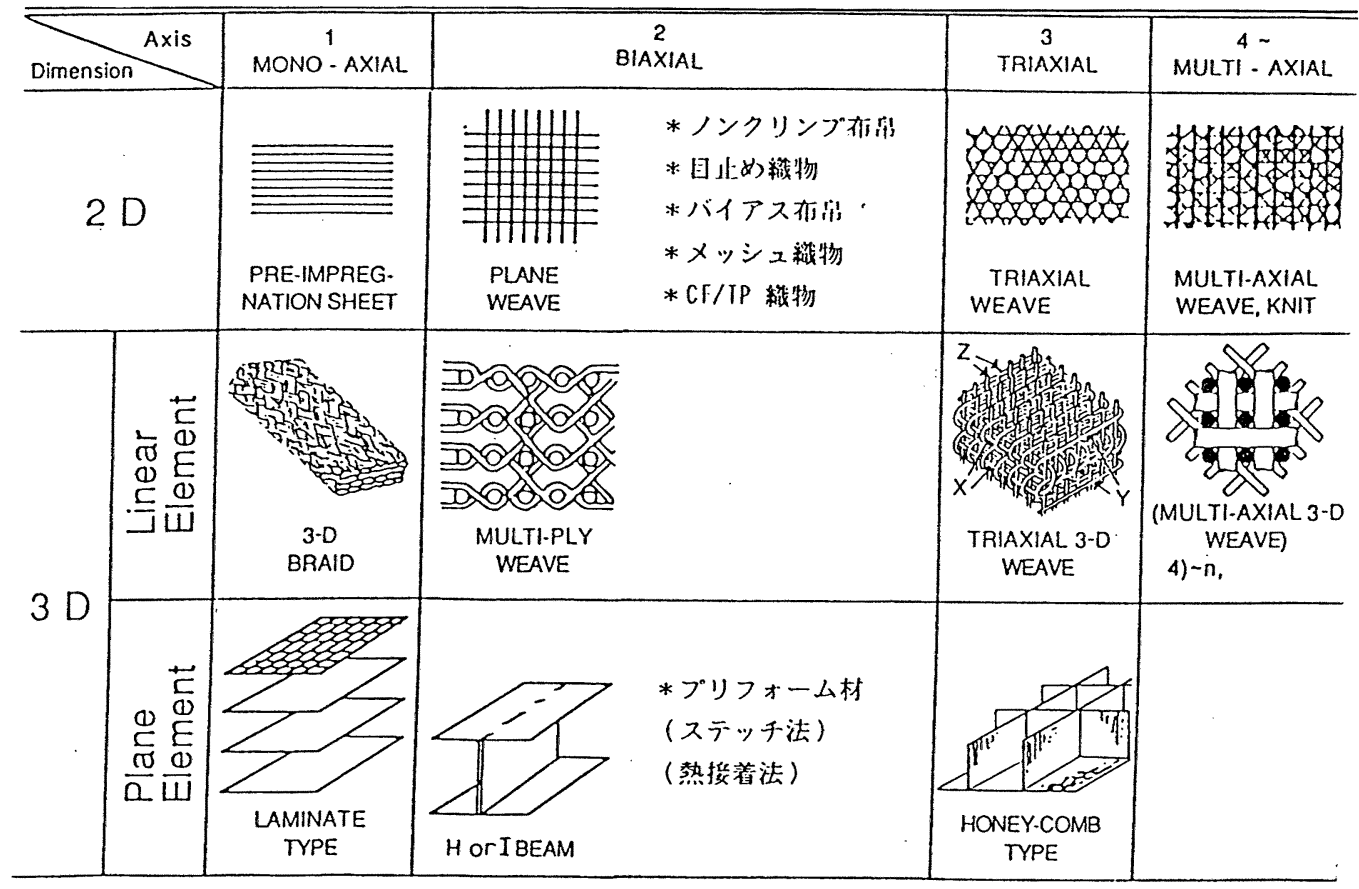


分かった ${ }^{8)}$.一方, この織角度 $\theta$ は, たて糸とよこ糸 の交錯状態を表すパラメーターであり, 織物組織, 織物密度や織糸繊度によって決まるが, 織角度が小 さくなれば，織物の形態が不安定になる。

そこで, CF 使用による織物設計を, 形態の安定 性は少々犠牲にし, 複合材料としての強度, 弾性率 の力学的特性がよく発現するようにした. 物性中心 の設計を行うことによって, 十分 $\mathrm{ACM}$ の材料とし て使用可能な状態であることが分かり，1976年，第 21回米国 SAMPE シンポジゥムで発表9, 10), 欧米の 大手航空機メーカーやプリプレグメーカーの関心を 引き付けた. それ以降,「トレカ」使用の織物が航空 機メ一カーの認定を得, CFRP 2 次構造材への展開 が進み, 現在, $70 \sim 80 \%$ が織物の形で使われてい る.

世界各国で主に用いられている織物は東レ設計の \#6343が原形をなしている.

織物の積層構成之設計成形品厚みの関係から, 薄 いCF 織物が要求されるケースが多い，織物設計の 立場からは, 細い系を使えば織物設計の自由度が大 きくなり, 形態の安定性にも配慮することができる が, 一般にCF の価格は糸条繊度が小さくなるほど 高くなる. 従って, 繊度の大きな系条で織物を設計 することが必要となる. 実際に上市されているCF 織物を, 織物目付 (厚さ) と糸条䋐度の関係で整理 すれば, 図2のようになる.

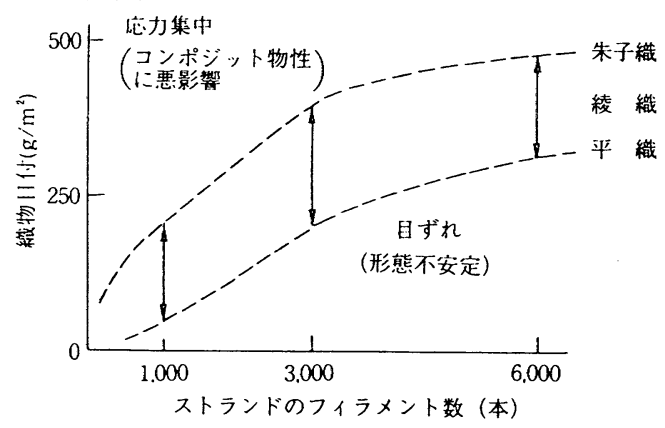

図 2 炭素䋐維織物の現状

\section{2 ノンクリンプクロス ${ }^{11)}$}

1978年，炭素繊維ノンクリンプクロス（図 3 ）を 考案 ${ }^{22} し ， 1983$ 年, 第28回米国 SAMPE シンポジゥ ムに発表 ${ }^{11}$ ，センセーショナルな反響があった。 そ れ以降, ノンクリンプ構造を有する布帛は, 編成や 接着による方法でも開発され, 布帛状の CF 中間基 材の理想的な形態とみなされるようになった，共通 点は高価な $\mathrm{CF}$ の特性を十分に発揮させるため, $\mathrm{CF}$
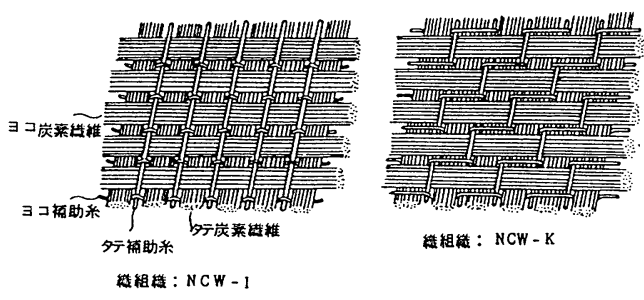

図 3 ノンクリンプクロスの組織

の布帛厚さ方向に対する屈曲（クリンプ）をなくし， 応力集中をできるだけ小さくしていることにある。 ノンクリンプクロス使用による複合材料は, 1 方向 プリプレグの $0^{\circ} / 90^{\circ}$ 交差積層品とほぼ同等の特性 が得られることを確認した。

なお，編成法によるノンクリンプ布帛は, 強化緎 維系条を細い補助系による編組織で布帛形成させ, 組織的には補助糸によって系条を拘束しているの で, 複合材料に成形したとき, 樹脂中における強化 繊維の分散が悪くなる。これに対し，ノンクリンプ クロスは織組織で布帛形成させているので $\mathrm{CF}$ 糸条 が拡がりやすく, 繊維体積含有率が大きくなり, 繊 維の分散性が良い, また, 補助系にはガラス繊維な ぞの強化繊維を用いることが可能であるなど, $\mathrm{ACM}$ の中間基材としての性能を持ち合わせてい る.

図 4 にノンクリンプ CF クロスを使用した複合材 料の引張特性を繊維体積含有率の関係で示した。， ンクリンプクロスは従来の $\mathrm{CF}$ 織物で観察された複 合則からの乘離考象は無く, 高強度の複合材料が得 られることが分かる。

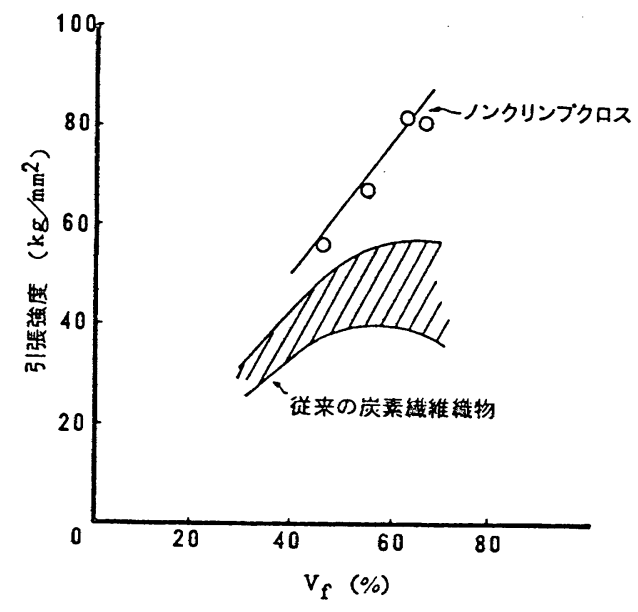

図 4 ノンクリンプクロスの引張強度 


\section{3 目どめ織物8)}

$\mathrm{CF}$ 織物は，複合材料物性重視の織物設計とした ため, “織物” の概念では合繊織物, 天然綫維織物や ガラス繊維織物に比へ，形態が不安定，すなわち八 ンドリング性が悪いという問題があった。

形態を安定にするには，何引かの接着剂で織物の たて糸とよこ糸を接着すれば良いのであるが，接着 斉の使用によってマトリックス樹脂の含浸が阻害さ れたり，物性低下を招くことがあってはならない． また, 織物材の特徵の一つに, 複雑な多次曲面に沿 う性質がある。織物がせん断変形することによる が，これら機能を保持していることあ必要である.

上記課題を満足する織物として，図 5 に示したよ うにたて糸とよこ糸が交差した箇所で，たて糸また はよこ糸の横腹部に接着剂を線状に配置する技術を 開発した，接着剤が付着している位置は，たて糸と よこ系を接着させるのに最む効果的な場所であるの で, $\mathrm{CF}$ 重量に対して $0.6 \%$ 2.5\%, また， $1 \mathrm{~m}^{2}$ 当 たり $1.0 \sim 3.0 \mathrm{~g}$ 程度の接着剂の使用によって, 織 物全体を均一に目どめすることが可能となった。

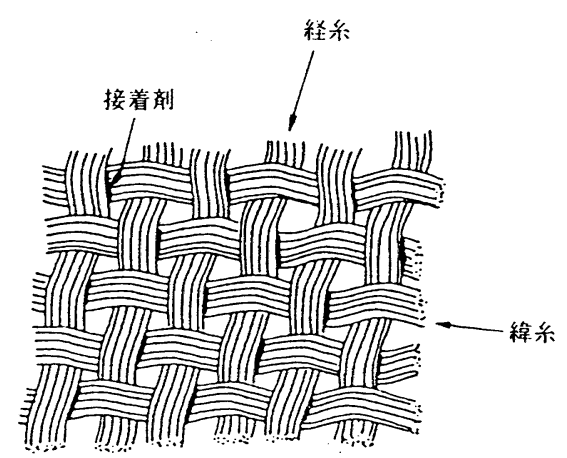

図 5 目どめ織物の構造

目よ゙め織物によって織物の裁断によるほつれが解 消され，またハンドレイアップ成形時の繊維配向乱 れも解消された。 ACM 成形の省力化法として，プ ルトルージョン成形や RTM (Resin Transfer Molding）成形技術が検討されているが，ガラス繊維強 化プラスチックスの場合とは異なり，正確な繊維配 向が必要とされ，この成形法に目どめ織物が有効と なろう。

\section{4 三軸織物 ${ }^{13)}$}

Norris F. Dow が連続的に三軸織物を製造する方
法を発明し ${ }^{14)}$ ， 米国で合成繊維を中心とした展開が なされていた.1980年，三軸織機のメーカーである バーバー・コールマン社にCF を送付し，世界で初 めて CF 三軸織物の研究に着手し，引き続き1981年 １983年の 3 年間、次世代産業基盤技術研究開発制 度に基づき，(財次世代金属・複合材料研究開発協会 が委託を受けた「複合材料の研究開発」の一環とし て行った.

$\mathrm{CF}$ を $60^{\circ}$ 交角で, 3 方向に配列した織物構造 （図6）となるので, 交差積層しなくとも疑似等方性 の特性を持つ複合材料が得られるはずである。1方 向に積層した硬化板の複合材料特性を図 $7 ， 8$ に示 したが, 引張強度, 引張弾性率とも角度依存性が小 さく，疑似等方性の特性が得られることを確認し た.

三軸織物は 1 枚で疑似等方性の特性が得られるの で，積層に当たって，1枚ごとの繊維配向精度が要 求されない, また, 交差積層で問題となる各層の物 性のミスマッチングによる層間の弱点などの解消が 期待される。製造装置である三軸織機は開発段階に

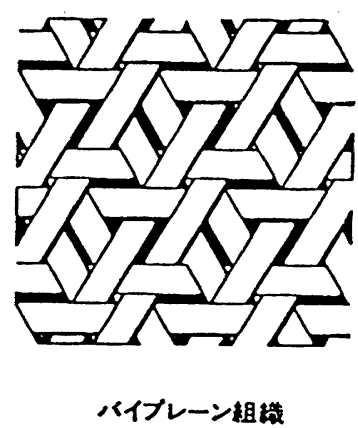

図 6 三軸織物の組織

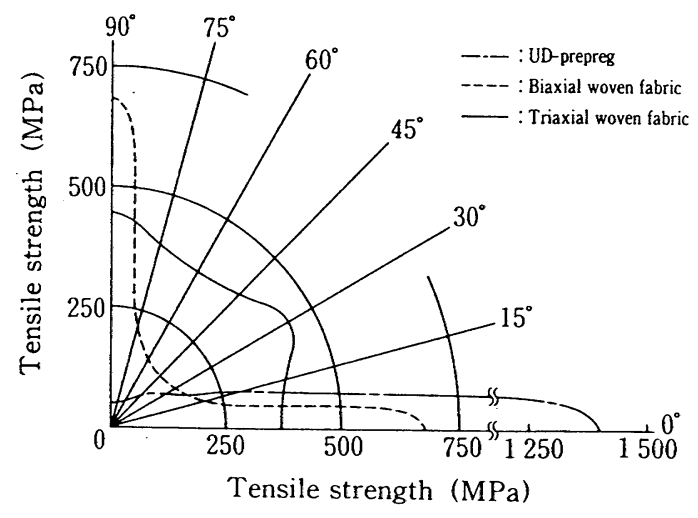

図 7 三軸織物の引張強度 


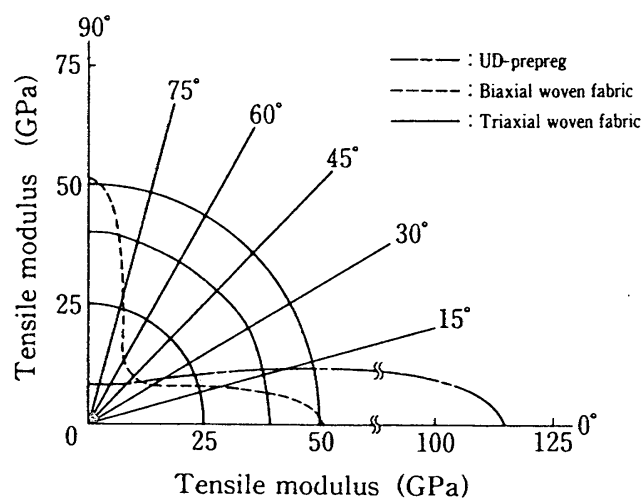

図 8 三軸織物の引張弾性率

あり， $\pm 30^{\circ}$ に配向しているバイアス糸の糸密度変 更に対する自由度が小さい，繊維配向の鏡面対称積 層が可能となる対の織物が製造出来ないなどの装置 上の課題はあるが, 今後, 改善が進むものと考える.

\section{5 ステッチド・プリフォーム}

$\mathrm{ACM}$ は，一般的には一次元または二次元方向に 強化繊維が配列したシート状の薄い基材の積層体か らなる. 従って, 面 $(\mathrm{x}-\mathrm{y})$ 方向には強化繊維が配 向しているので, 高性能な力学的特性が得られる が, 厚さ（z）方向には強化䋐維が存在しないので, 層間の特性は繊維と樹脂の接着力や樹脂の強度によ って決まり弱い。

改善策とし，基材の層間にインターリーフを設け るとか, 最近, 三次元方向に繊維が配向した織物や 組紐の開発が進められているが，層間のインターリ 一フは成形法がオートクレーブに制限されるとか, 一方, 三次元織物や組紐は，繊維の配向に制限があ り汎用的な材料とはなりがたい，生産性が悪い，一 品一様の製造機が必要になるなど汎用性の問題があ る.これに対し, 面 $(\mathrm{x}-\mathrm{y})$ 方向の繊維配向は従来 の積層体と全く同じにし，層方向のみを補強すると

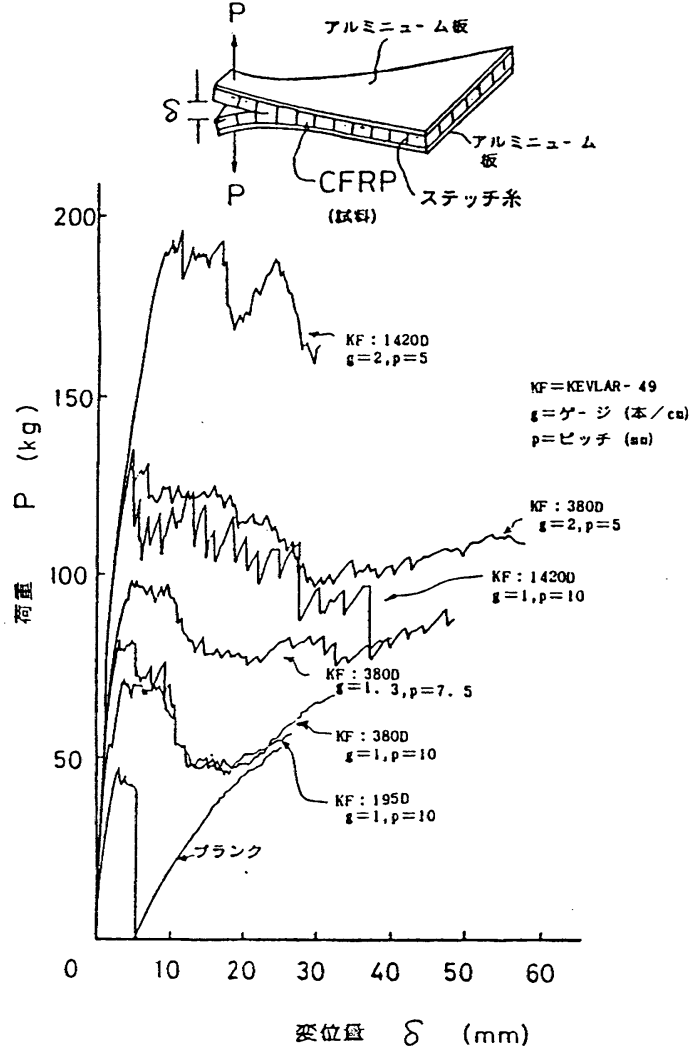

図10 層間剝離に対するステッチ効果

のコンセプト16)のもとに，1981年からステッチド・ プリフォームの研究・開発に着手した（図 9 ).

アラミド繊維をステッチ糸として，CFRP 積層板 の層間の引きはがしに対する効果を調査した結果を 図10に示した。 ステッチ系の太さやステッチ密度, すなわちステッチ繊維密度が大きくなるに従い，引 きはがし抵抗力が大きくなり，ステッチ糸が層間強 化の役割を果たしていることが分かる。これらの性 質は層間に発生するクラックの伝播を阻止し，衝撃 によって発生する層間㔀離を小さくし，エッジデラ

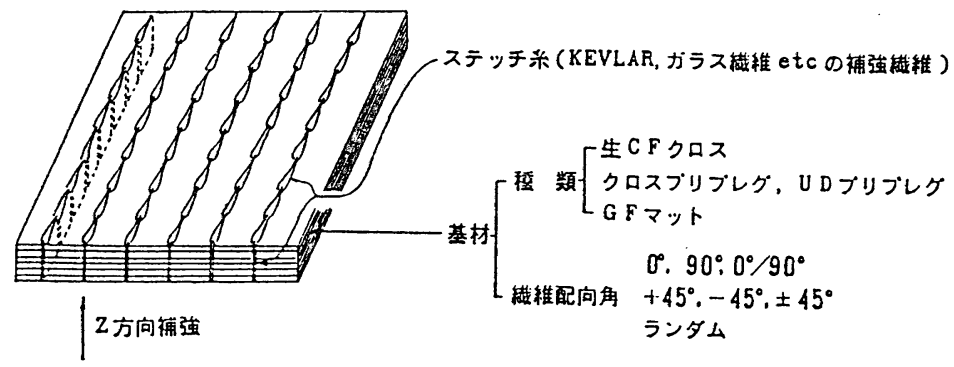

図 9 ステッチド・プリフォームの概念図 
ミネーションを阻止するなど，CFRP を構造材料と して展開しようとした場合，好ましい効果をもたら す.

最近, 結節強力の高い炭素繊維のステッチ系む開 発し17), 米国の航空機メーカーを中心に, CF 複合材 料への実用化研究が始まっている.

なお，ステッチド・プリフォームは，ACM の低 コスト成形法として技術開発が進められている，プ ルトルージョン成形や RTM 成形にも適用すること ができ, 将来が期待される.

\section{4. 成形法の進歩}

\section{1 積層工程}

航空機部品の大半は，シート状のプリプレグを繊 維軸が所定の方向になるように, 型に多数枚交差積 層し，これをフイルムでバッグし，オートクレーブ 成形機で加熱・加圧し，樹脂を硬化する方法で作ら れるが，この積層作業は人間が手積で行っている。 人為的ミスに対する管理が大変であり，同時に積層 に多くの時間が必要となる。最近，細く裁断された 1 方向のプリプレグ・テープを型に積層するオート レイアップマシンが開発され，大手の航空機メ一カ 一は採用を開始している. また, 複雑な形状の成形 品を作るに当たって，より繊維配向が正確になるよ うにトウ・プレイスメント ${ }^{18}$ の技術開発む始まって いる.

\section{2 成形工程}

\section{(1)RTM 成形}

レジィ・インジェクション（RI）成形ともいわれ ている， RTM成形法は，プルトルージョン成形法 之同様，すでに GFRP 分野で実用化されているが, $\mathrm{ACM}$ の成形法として RTM が取り上げられ，技術 開発が始まった発端は，ガラスマットを使った GFRP 製品の繊維体積含有率が $20 \%$ に対して, 炭 素繊維織物では $50 \sim 60 \%$ が可能であり, 十分高性 能な複合材料を狙えることが判明したことによるす のと考えられる.

\section{(2)プルトルージョン成形}

本成形法の基本的な工程は，繊維束や織物などの 基材に樹脂を含浸し，ダイの中で加熱し，ゲル化し た状態で賦形，固化させるもので連続生産が可能で ある. 工程的には極めて単純で, FRP 成形法のなか では最も機械化され，量産に向く方法があるが，繊
維補強方向の制限，繊維配向精度が悪いという問題 がある. 最近，所定の方向に繊維配向した織物を積 層し，ステッチ加工を施したプリフォーム材を供給 する方法も試みられている ${ }^{199}$.

\section{5.おわりに}

米国における CFRP 製航空機部品の原価分析の 一例を図 11 に示す ${ }^{20}$. 材料費の占める割合が $20 \%$ 弱 に対して，中間基材の加工費，成形費等の加工費の 割合が大きく，なかでも成形加工費が $2 / 3$ を占め ている，軽量化によるメリットが大きいとされてい る航空機部品用途ではあるが，成形工程における効 率化が大きな課題となっており，中間基材を含めて コストダウンに対する検討が始まっている.

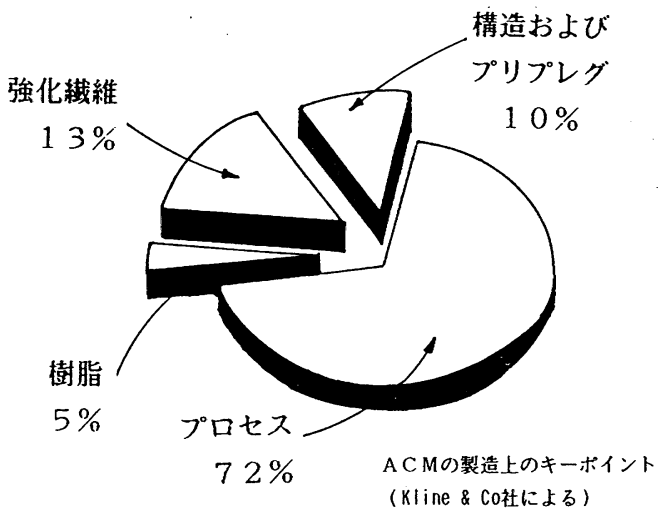

図11 航空機 CFRP 部品の原価分析

今後, ACM 分野で中間基材，すなわち繊維高次 加工技術への期待はますます大きくなり，今後の課 題をまとめれば，次のようになろう。

（1）積層体の厚さ方向も含めて, 繊維配向に対す る自由度の大きい中間基材や繊維高次加工技 術開発.

（2）成形工程の効率化が可能となる中間基材およ び加工技術開発.

幸いなことに，中間基材を製造する繊維高次加工 産業は徹底した合理化がなされ，加工技術水準も高 い. 本報告で解説した中間基材もこれらの土塨から 生まれたものであるが，織物設計技術や製造技術な どを駆使することによって，今後の複合材料の発展 に寄与することが可能であろう。

参考文献

1) A. Andrews; Back to the Drawing Board-The Evalution of Flying Machines.

2) Letter, W. E. Boeing to Western Dry Goods Co., Boeing 
Historical Library (June, 1, 1916)

3) 山根等; 32 nd SAMPE, p. 298, 1987

4）東レ(株) “トレカ”商品資料, PD-YN 3 / 1991-11

5）例えば, 林 毅編; 複合材料工学, 日科技連 p. 6, (1972)

6) A. Nishimura, \& S. Matsuda; Conference, Reinforced Plastics 79 with Internatinal Participation（チェコスロ バキア)

7) 西村 明, 松田 滋; 強化プラスチックス, 26, 3, 12-17, (1980)

8）西村 明; プラスチックエージ，35，150-156, (1989)

9) N. Shibata, A. Nishimura, T. Norita ; 21 th SAMPE Symp. (1976)

10）西村 明, 柴田尚幸; 強化プラスチックス，19，12，1-7 (1973)

11) A. Nishimura, N. Ueda \& S. Matsuda; 28th SAMPE Symp. pp. $71-88$, (1983)

12）特公昭 $57-52221$, U. S. P. 4320160

13）堀部郁夫, 本間 清, 西村 明; 第 19 回 FRP シンポジウ ム, 16-19, (1989)

14) U. S. P. 3446251.

15) A. Nishimura \& H. Aotani Composite 86: Recent Advances in Japan and the United States pp. 29-36, (1986)

16）例えば, 特公昭 $62-27184$.

17) Y. Mathuhisa, T. Hiramathu \& A. Nishimura; 33rd
SAMPE Sympo., 33 pp. $91-103$, (1988)

18) M. L. Enders, P. C. Hopkins; 36th SAMPE Sympo. pp. $778-790$ (1991)

19) M. L. Wilson, G. S. Johnson, R. Miserention; 42nd SPI, 1 -A (1987)

20) Mordern Plastics, September pp. 22 - 26, (1988)

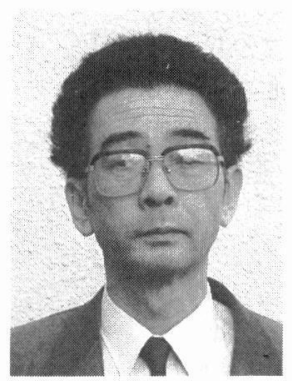

西村 明（にしむらあきら） 昭和39年金沢大学工学部機械工 学科卒, 同年東レ(株入社, 同47 年まで WJL などの革新繊維機 械の研究開発に従事, その後炭 素繊維織物を始めとする ACM 中間基材の研究・開発および用 途開発に従事し現在に至る. 現 在同社複合材料研究所研究主幹 (東レ(梀複合材料研究所, $=791$ -31 愛媛県伊予郡松前町大字 筒井1515, TEL. 0899-84-2121, FAX. 0899-84-9491)

\section{投稿歓迎}

繊維工学編集委員会では, 下記のような種類の原稿の投稿を歓迎します。学問的, 技術 的知見, 経験などで, 公開できるものはできるだけ多く「繊維工学」誌上にご発表いただ き, 会員の相互啓発, 我国の学界, 産業界の発展に寄与されることを希望します.

総説 : 提案, 意見, 批評等の論説および研究, 技 術, 経済等の総合的な記事

技術 解 説 : 繊維工業分野に直接あるいは間接に関係す る考察，改良，工夫等を含む内外の工業技 術, 重要卜ピックス等の解説記事

研 究 解 説 : 研究論文の平易な解説記事

講義 : 系統的でまとまった知識を与える記事

資料：調查, 解説等の技術的に価值ある資料

製品紹介：技術的に優れた製品の紹介

報 告 記: 学校, 研究所, 会社等の見学記録, 対談,
てい談, 座談会および研究会等の報告記事 と記録その他

\section{投稿後の原稿の取り扱い}

1. 原稿の採否, 分類等については緎維工学編集委員 会で決定します。また, 依頼あるいは投稿された 原稿は専門分野の査読委員が査読し訂正を求める ことがあります。

2. 校正は原則として初校で 1 回お願いします.

3. 版権は本会に属します。 